Crops and Products

Elsevier Editorial System(tm) for Industrial

Manuscript Draft

Manuscript Number: INDCRO-D-17-01209R2

Title: Insecticidal activity in Tithonia diversifolia and Vernonia amygdalina

Article Type: SI: ICPP2

Section/Category: Non-food bioactive products

Keywords: Callosobruchus maculatus, sesquiterpenes, botanical insecticide, pesticidal plants, saponins.

Corresponding Author: Professor Philip C. Stevenson, PhD Chemical Ecology

Corresponding Author's Institution: Royal Botanic Gardens and University of Greenwich

First Author: Paul W Green, PhD

Order of Authors: Paul W Green, PhD; Steven R Belmain, PhD; Patrick A Ndakidemi, PhD; Iain W Farrell, PhD; Philip C. Stevenson, PhD Chemical Ecology

Abstract: The diversity of synthetic pesticides has been reduced through regulation especially in the European Union leading to a resurgence of interest in natural plant products for pest control. Here we investigated two Asteraceae species, Tithonia diversifolia and Vernonia amygdalina that are used by farmers in Africa in bio rational pest control to determine the chemical basis of activity against pests of stored legumes and identify plant compounds with commercial potential. The cowpea beetle, Callosobruchus maculatus, an ubiquitous pest of African stored grain legumes, was exposed to extracts of both plant species at 10,1 and $0.1 \% \mathrm{w} / \mathrm{v}$ and fractions of these extracts at representative concentrations. Extracts and fractions were toxic to recently emerged adults, but did not reduce oviposition by those females that survived. The sesquiterpene, Tagitinin A, was isolated from one of the active fractions and identified using H1 and C13-NMR and shown also be toxic to $\mathrm{C}$. maculatus and so partially explains the activity of the whole plant. Other compounds in the active fractions were identified, at least to structural class, using high resolution mass spectroscopy (HRESI-MS). Sequiterpenes and flavones were common to fractions from both plants. Stigmostane steroidal saponins were the most abundant secondary metabolites in V. amygdalina. 


\title{
Insecticidal activity of Tithonia diversifolia and Vernonia
}

\section{amygdalina}

Paul W.C. Green ${ }^{\text {a, } 1}$, Steven R. Belmain ${ }^{\text {b }}$, Patrick A. Ndakidemi ${ }^{\text {c }}$, Iain W. Farrell ${ }^{\text {a }}$, Philip C. Stevenson $^{a, b, *}$

${ }^{a}$ Royal Botanic Gardens, Kew, Richmond, Surrey. TW9 3AB, U.K. p.stevenson@kew.org, + 44 (0)20 83325377.

${ }^{\mathrm{b}}$ Natural Resources Institute, University of Greenwich, Central Avenue, Chatham Maritime, Kent. ME4 4TB, U.K. +44 (0)1634 883212

${ }^{c}$ School of Life Sciences and Bioengineering, Nelson Mandela African Institute of Science and Technology, P.O. Box 447, Tengeru, Arusha, Tanzania.

${ }^{1}$ present address, Syngenta, Jealott`s Hill International Research Centre, Bracknell, Berkshire RG42 6EY, U.K.

* Corresponding author

\begin{abstract}
The diversity of synthetic pesticides has been reduced through regulation especially in the European Union leading to a resurgence of interest in natural plant products for pest control. Here we investigated two Asteraceae species, Tithonia diversifolia and Vernonia amygdalina that are used by farmers in Africa in bio rational pest control to determine the chemical basis of activity against pests of stored legumes and identify plant compounds with commercial potential. The cowpea beetle, Callosobruchus maculatus, an ubiquitous pest of African stored grain legumes, was exposed to extracts of both plant species at 10,1 and $0.1 \%$
\end{abstract}


$\mathrm{w} / \mathrm{v}$ and fractions of these extracts at representative concentrations. Extracts and fractions were toxic to recently emerged adults, but did not reduce oviposition by those females that survived. The sesquiterpene, Tagitinin A, was isolated from one of the active fractions and identified using $\mathrm{H}^{1}$ and $\mathrm{C}^{13}$-NMR and shown also be toxic to $C$. maculatus and so partially explains the activity of the whole plant. Other compounds in the active fractions were identified, at least to structural class, using high resolution mass spectroscopy (HRESI-MS). Sequiterpenes and flavones were common to fractions from both plants. Stigmostane steroidal saponins were the most abundant secondary metabolites in $V$. amygdalina.

Keywords Callosobruchus maculatus, sesquiterpenes, botanical insecticide, pesticidal plants, saponins.

\section{Introduction}

Legume seeds provide food, are sold for profit and used for sowing subsequent crops, so it is particularly essential for small holder farmers in developing countries to minimise insect damage during periods of seed storage (Sola et al. 2014). Callosobruchus maculatus (L.) (Coleoptera: Bruchidae) is a significant pest of stored legumes throughout Africa (Abate and Ampofo 1996), the Middle East, India and South America feeding on and contaminating the stored seeds (Tuda et al. 2006), especially cowpea, Vigna unguiculata L. Walp (Ehlers and Hall 1997). It is possible to control C. maculatus using synthetic pesticides e.g. (Hill 1983) but these are expensive and require specialist equipment and training to be safely and effectively applied (Matthews et al. 2014). Synthetic pesticides can be toxic or have sublethal effects on the wider invertebrate community of beneficial insects, such as parasitoid wasps that can contribute to the control of bruchid pests (Van Alebeek 1996). A cost- 
effective and environmentally benign way of protecting crops is to use extracts or powdered plant materials of locally available insecticidal plants, and there are a number of examples of these being successfully employed to kill insects and decrease crop losses (Hagemann et al. 1972; Stevenson et al. 2009; Mwine et al. 2011; Belmain et al. 2012; Stevenson et al. 2012; Amoabeng et al. 2013). More recently, field trials testing Tithonia diversifolia (Hemsl.) A.Gray (Asteraceae) and Vernonia amygdalina Delile (Asteraceae) against field pests of common beans (Phaseolus vulgaris L.) demonstrated that extracts were as effective at controlling pest insects as a synthetic pyrethroid (Mkenda et al. 2015a). Extracts of $T$. diversifolia and $V$. amygdalina consist of a range of insecticidal compounds, especially volatile and non-volatile terpenoids (Ganjian et al. 1983; Ambrósio et al. 2008; Adeniyi et al. 2010; Madkour et al. 2013; Mkenda et al. 2015a). Some data report that polyphenolic compounds in $T$. diversifolia extracts inhibit the glutathione-s-transferases of $C$. maculatus (Kolawole et al. 2011) and could explain the lethal effects of the plant extract. Determining the chemical basis of activity in pesticidal plants can inform methods for optimising their use and identify potential candidate compounds for commercialisation (Stevenson et al. 2016). Furthermore, experimentation with the extraction process can alter the yield of compounds and alter efficacy. As part of continuing work on optimising the use pesticidal plants, here, we determine the plant chemistry underlying the biological activity of $T$. diversifolia and $V$. amygdalina and discuss scope for improving application of these species for pest control in Africa. 


\section{Methods}

\subsection{Preparation of extracts and fractions}

\subsubsection{Extraction}

Dried leaves from Vernonia amydalina and Tithonia diversifolia were obtained from the Kilimanjaro Region, northern Tanzania (Latitude $3^{\circ} 13$ '59.59’'S Longitude 37²1'54’'E) and voucher specimens were deposited at Nelson Mandela African Institution of Science and Technology, Arusha, Tanzania. Powdered material of each plant was extracted in methanol at a rate of $100 \mathrm{mg}$ of plant material per $\mathrm{mL}$ of solvent $(10 \% \mathrm{w} / \mathrm{v})$. Extracts were filtered and the solvent evaporated to yield $2.94 \mathrm{~g}$ of dried extract from $25.6 \mathrm{~g}$ of $V$. amygdalina and $1.93 \mathrm{~g}$ from $24.9 \mathrm{~g}$ of $T$. diversifolia. So, each gram (100mg) of plant material yielded $114.8 \mathrm{mg}$ (11.48mg) and $77.4 \mathrm{mg}(7.74 \mathrm{mg})$ of dried extract for $V$. amygdalina and $T$. diversifolia, respectively. Samples of dried extract were re-dissolved in methanol to $10 \% \mathrm{w} / \mathrm{v}$ equivalence for bioassay (11.48 and $\left.7.74 \mathrm{mg} \mathrm{mL}^{-1}\right)$ and further diluted to $1 \%\left(1.15\right.$ and $\left.0.774 \mathrm{mg} \mathrm{mL}^{-1}\right)$ and $0.1 \%\left(0.12\right.$ and $\left.0.08 \mathrm{mg} \mathrm{mL}^{-1}\right)$ to determine dose effects. Stock-solutions of $100 \mathrm{mg} \mathrm{mL}^{-1}$ of dried extract in methanol were used for fractionation.

\subsubsection{Fractionation}

An HPLC system consisting of a Waters 2695 separations module linked to a 2996 photodiodearray detector (PDAD) was used for fractionation of extracts. Aliquots of $T$. diversifolia extract $(200 \mu \mathrm{L})$ were injected onto a Phenomenex Luna RP18 column $(300 \times 10$ $\mathrm{mm}$, length $\times$ i.d.; $10 \mu \mathrm{m}$ particle size) and eluted at $4 \mathrm{~mL} \min ^{-1}$ using a linear gradient of 40\%A: $10 \% \mathrm{~B}: 50 \% \mathrm{C}(\mathrm{t}=0)$ to $90 \mathrm{~A}: 10 \mathrm{~B}: 0 \mathrm{C}(\mathrm{t}=20-25 \mathrm{~min})$ returning to the starting conditions $(\mathrm{t}=27 \mathrm{~min}$ ), where $\mathrm{A}=$ methanol; $\mathrm{B}=1 \%$ formic acid in acetonitrile and $\mathrm{C}=\mathrm{HPLC}$-water. The fractionation of $V$. amygdalina used a shorter column $(150 \mathrm{~mm})$ different initial conditions $(\mathrm{A}=30 \% ; \mathrm{B}=10 \% ; \mathrm{C}=60 \%)$ and a non-linear gradient (Waters, curve=7) to enhance the 
separation of compounds with similar retention times. The quantity of material injected and the proportion of each fraction in a $10 \% \mathrm{w} / \mathrm{v}$ extract was calculated. The fractions contributed from $0.17(\mathrm{~F} 2)$ to $0.50 \mathrm{mg} \mathrm{mL}^{-1}$ (F4) (Vernonia) and from 0.08 (F3) to $0.49 \mathrm{mg}$ $\mathrm{mL}^{-1}(\mathrm{~F} 1)$ Tithonia.

\subsection{Experimental}

\subsubsection{Insects}

Callosobruchus maculatus (Fabricius, 1775) were a wild Ghanaian strain, originally collected in 1995. They were housed in a temperature controlled room $\left(28 \pm 1{ }^{\circ} \mathrm{C}, 55 \% \mathrm{RH}\right)$ that was kept in permanent darkness. Adults laid eggs on cowpea seeds Vigna unguiculata and 24 to 28 days later the next generation of adults emerged from the beans. The insects used for bioassays were 3-5 days post-emergence.

\subsubsection{Bioassay procedure}

Fractions and residue were dissolved to concentrations representing their proportions in 10,1 and $0.1 \% \mathrm{w} / \mathrm{v}$ extracts of each plant species. Aliquots $(75 \mu \mathrm{L})$ of compounds, extracts, methanol (negative control) or rotenone (1000 and 100ppm, positive control) were evaporated onto vials $(25 \mathrm{~mL}$, nominal capacity) under a stream of air and with constant rotation of the vial. Insects $(\mathrm{N}=5-12)$ were added to the vials, ensuring a ratio of at least 1:1 (male to female). 5 black eyed beans were added to each vial after $72 \mathrm{~h}$. After a further $72 \mathrm{~h}$ mortality was recorded. The numbers of eggs laid on both the vials and the beans were counted and from these data the eggs laid per female were calculated. ANOVA followed by Tukey`s HSD post hoc test (95\% C.I.) were used to compare the mortality and eggs laid among and between treatments at equivalent concentrations (XLSTAT version 2015.1.03.16409). 


\subsection{Analyses}

\subsection{1. $L C-M S$}

Accurate mass measurements of compounds detected in the extracts were obtained using an LTQ Orbitrap XL, linear ion trap/orbitrap hybrid mass spectrometer (Thermo Scientific, San Jose, California USA) with an electrospray ionisation source (Ion Max, Thermo Scientific) coupled to an "Acella 1250" UPLCsystem (Thermo Scientific). Samples were injected onto a Phenomenex Luna C18(2) column $(150 \times 3 \mathrm{~mm}$ i.d., $3 \mu \mathrm{m}$ particle size $)$ at $400 \mu \mathrm{L} \mathrm{min}{ }^{-1}$ and eluted using a linear gradient of 90:0: $10(t=0 \mathrm{~min})$ to 0:90:10 $(\mathrm{t}=20-25 \mathrm{~min})$, returning to 90:0:10 ( $\mathrm{t}=27-30 \mathrm{~min})$. Solvents were water, methanol and 1\% formic acid in acetonitrile, respectively. The column was maintained at $30^{\circ} \mathrm{C}$. Samples were scanned, using FTMS, from $m / z$ 250-2000 in both positive and negative modes. Samples were first matched with those reported from $T$. diversifolia and $V$. amygdalina in the Combined Chemical Dictionary(CCD, 2017), by using the $m / z$ to calculate putative molecular formulae. Where compounds could not be matched to compounds known from these two species the search was extended first to the generic level, then to the Asteraceae and finally to other sources.

\subsection{2. $N M R$}

NMR spectra were acquired in acetone- $d_{6}$ at $30{ }^{\circ} \mathrm{C}$ on a Bruker Avance $400 \mathrm{MHz}$ instrument, with a $5 \mathrm{~mm}$ BBO probe. Standard pulse sequences and parameters were used to obtain onedimensional ${ }^{1} \mathrm{H}$ and ${ }^{13} \mathrm{C}$ spectra. A two-dimensional NOE spectrum was obtained in phasesensitive mode with HDO presaturation and a mixing time of $800 \mathrm{~ms}$. The Bruker microprograms were used for COSY (90 degree flip pulse), HSQC (multiplicity-edited) and HMBC (optimised to ${ }^{\mathrm{n}} J_{\mathrm{CH}}=8 \mathrm{~Hz}$ ) experiments, with appropriate adjustments in gradientselection mode. Chemical shifts were referenced to tetramethylsilane as the internal standard. 


\section{Results}

\subsection{Bioassays}

Crude extracts of $T$. diversifolia and $V$. amygdalina were toxic to $C$. maculatus in a dose dependent manner, with $T$. diversifolia generally more toxic than $V$. amygdalina (Table 1). However, the crude extracts showed no significant effects on oviposition, even at the highest dose tested (Table 1; ANOVA, P > 0.05). All chemical fractions from both plant species were toxic in comparison to the untreated control. Many fractions showed comparably high mortality as that achieved with the standard, rotenone, particularly fractions 1,2 and 5 from T. diversifolia and fractions 1,2 and 4 from $V$. amygdalina (Table 1). With respect to oviposition, fractions 2 and 5 from $T$. diversifolia were able to inhibit oviposition; however, none of the fractions from $V$. amygdalina were able to significantly reduce oviposition (Table 1).

\subsection{Characterisation of compounds}

Fraction 1 (F1) from $T$. diversifolia recorded a single peak in the LC-MS chromatogram occurring after $10.1 \mathrm{~min}$ and which consisted of three major ions with $\mathrm{m} / \mathrm{z} 413.18054[\mathrm{M}+$ $\mathrm{HCOO}^{-} ; 781.36365\left[2 \mathrm{M}+\mathrm{HCOO}^{-}\right.$and $367.17517[\mathrm{M}-\mathrm{H}]^{-}$, calculating for the molecular formula $\mathrm{C}_{19} \mathrm{H}_{28} \mathrm{O}_{7}$ and corresponding to tagitinin A (Figure 1). The NMR data were broadly in agreement with published data for tagitinin $\mathrm{A}$ in acetone- $d_{6}$ (Glaser et al. 2005), and in $\mathrm{CDCl}_{3}$ (García et al. 2006). In acetone- $d_{6}$ no evidence of isomerisation could be observed based on a additional $1 \mathrm{D}$ proton spectra after the acquisition of all the other spectra $\left(1 \mathrm{D}{ }^{13} \mathrm{C}\right.$ and 2D). The complete signal assignment is presented in Table S2. 
Compounds were identified from other fractions of $T$. diversifolia and $V$ amygdalina using accurate mass measurements $(\mathrm{m} / \mathrm{z})$ of major ions to calculate molecular formulae for compounds known from these or related species. Three classes of compounds were identified in fractions from T. diversifolia. Flavones: homohesperitin (F2) and hispidulin (F3) (Figure 2); sequiterpene lactones: tagitinins $\mathrm{A}(\mathrm{F} 1$ and F2), B (F2), C (F3, 4 and 5), D (F3) and H (F5) (Figure 1) together with germacren-12,6-olides (F2 to F5) and a guiaiene-12,6-olide (F4) (Table 2). Ten compounds were tentatively identified in fractions of $V$. amygdalina. These compounds included sesquiterpenes (11,13-dihydrovernodalin, F1) (Figure 3); sesquiterpene lactones (vernodalinol and vernodalol, F1) (Figure 3); flavones (cynaroside, F1 and F3; luteolin hexuronide, F1; luteolin and luteolin methyl ether, F2; homohesperitin 7-rutinoside, F5) (Figure 2) and a dimethyl, dihexosyl ester of caffeic acid (F1) (Figure 4; Table 2). Due to the structural similarity between many of the remaining compounds in F3 to F5 they were categorized into structural classes, such as vernoniosides (F3 to F5) and less polar vernocuminosides/vernoamyosides (F4 and F5) (Figure 5; Table 2).

\section{Discussion}

The data presented here showed that extracts of $T$. diversifolia and $V$. amygdalina were toxic to $C$. maculatus, and that this activity was at least in part explained by sesquiterpene lactones in the whole extracts and chromatographically separated fractions. Biological activity in these plant species has been reported before where extracts of $T$. diversifolia suppressed populations of a range of insects and fungal pathogens under field conditions (Owolade et al. 2004), common bean field pests (Mkenda et al. 2015b), leaf-cutting ants (Castaño-Quintana et al. 2013) and deterred feeding of Chlosyne lacinia (Geyer) (Lepidoptera: Nymphalidae) larvae (Ambrósio et al. 2008). V. amygdalina oils and extracts have been shown to be toxic to stored product pests (Asawalam E. F et al. 2008; Adeniyi et al. 2010) and both repellent 
and toxic to Spodoptera exempta (Walker) (Lepidoptera: Noctuidae) larvae (Ganjian et al. 1983).

Our research showed that methanol extracts of both plant species were equally effective against bruchids whereas earlier work (Mkenda et al. 2015a) reported extracts of $T$. diversifolia to be less insecticidal than extracts of $V$. amygdalina on a range of field pests of common beans. Besides the different target pest species, the observed differences may be partly explained by the method of extraction. Mkenda et al., (2015b) extracted plants in water with $0.1 \%$ soap for field crop application whereas in the present work methanol was used and may have extracted biologically active non-polar compounds from $T$. diversifolia more effectively. Fractionation produces mixtures of compounds of varying polarity that are usually as toxic as the complete extract at representative concentrations. Extracts and fractions are broadly as effective as the known insecticidal compound, rotenone which was used as a positive control. It has been reported that 150 different compounds have been isolated from T. diversifolia (Zhao et al. 2012). In the Combined Chemical Dictionary, 22 compounds are listed from $T$. diversifolia and 14 from $V$. amygdalina $(\mathrm{CCD}, 2017)$ although this generally excludes the more ubiquitous compounds, such as the luteolin derivatives that we have identified. The extracts present pest insects with multiple chemical challenges. Furthermore, there is evidence that extracts are useful as antimicrobials (Erasto et al. 2006; Orsomando et al. 2016) and are toxic to parasitic protozoa (de Toledo et al. 2014; Abay et al. 2015) which would make them more useful to rural communities, particularly as they are easily cultivated. T. diversifolia is a globally invasive weed (Yang et al. 2012) and a particular problem in Africa (Henderson 2007) where its collection and use as a pesticide could help reduce its environmental impacts. Alternatively, flowering field margin plants can be important for providing food and refuge for beneficial insects (Mkenda et al. 2015b; Gurr 
et al. 2017), and pesticidal plants grown in field margins could support ecosystem services of natural enemies and pollinators.

\section{Conclusion}

Along with evidence from earlier published work (Ambrósio et al. 2008; Mkenda et al. $2015 \mathrm{~b}, \mathrm{~b}$ ), we conclude that the biological activity of the sesquiterpene tagitinin A presents a potential target molecule for commercialisation (Dutta et al. 1986) However, the non-target toxicity of this compound must not be overlooked, where further research is required to ensure safety (Passoni et al. 2013). Pesticidal plants can vary in their efficacy due to genetic or environmental differences (Belmain et al. 2012; Stevenson et al. 2012). A combination of chemotyping plants together with laboratory and field trials could help determine the conditions that maximise the quality and quantity of insecticidal components. This approach, emphasised by Isman and Grieneisen (2014) would help explain variability, while increasing efficacy and uptake of effective pesticidal plants by farmers.

\section{Acknowledgements}

This research was funded by a McKnight Foundation grant (Grant No: 13-335) https://www.mcknight.org/grant-programs/international/collaborative-crop-research and a European Union 9th European Development Fund grant from the African Caribbean and Pacific Science and Technology Programme (FED/2013/329-272) http://www.acp-st.eu/. The funders had no role in study design, data collection and analysis, decision to publish, or preparation of the manuscript. We thank Drs. G. Kite and T. Kokubun for technical support and Dr R. Grayer for help with interpretation of UV-spectra. 


\section{References}

Abate, T., Ampofo J.K., 1996. Insect pests of beans in Africa: their ecology and management. Annu. Rev. Entomol. 41, 45-73. doi: 10.1146/annurev.en.41.010196.000401

Abay, S.M., Lucantoni, L., Dahiya, N., Dori, G.,Dembo, E.G., Esposito, F., Lupidi, G., Ogboi, S., Ouédraogo, R.K., Sinisi, A., Taglialatela-Scafati, O., Yerbanga, R.S., Bramucci, M., Quassinti, L., Ouédraogo, J.B., Christophides, G., Annette Habluetzel, A., 2015. Plasmodium transmission blocking activities of Vernonia amygdalina extracts and isolated compounds. Malar. J. 14, 288. doi: 10.1186/s12936-015-0812-2

Adeniyi S.A., Orjiekwe, C.L., Ehiagbonare, J.E., Arimah, B.D., 2010. Preliminary phytochemical analysis and insecticidal activity of ethanolic extracts of four tropical plants (Vernonia amygdalina, Sida acuta, Ocimum gratissimum and Telfaria occidentalis) against beans weevil (Acanthscelides obtectus). Int. J. Phys. Sci. 5, 753-762.

Ambrósio, S.R., Oki, Y., Heleno, V.C.G., Siqueira Chaves, J., Dantas Nascimento, P.G.B., Espada Lichston, J., Gomes Constantino, M., Varanda, E.M., Batista Da Costa, F., 2008. Constituents of glandular trichomes of Tithonia diversifolia: relationships to herbivory and antifeedant activity. Phytochemistry 69, 2052-60. doi: 10.1016/j.phytochem.2008.03.019

Amoabeng, B.W., Gurr, G.M., Gitau, C.W., Nicol, H.I., Munyakazi, L., Stevenson, P.C., 2013. Tri-trophic insecticidal effects of African plants against cabbage pests. PLoS One 8, e78651. doi: 10.1371/journal.pone.0078651

Asawalam E. F, Emosairue S. O., Hassanali A., 2008. Contribution of different constituents to the toxicity of the essential oil constituents of Vernonia amygdalina (Compositae) and Xylopia aetiopica (Annonaceae) on maize weevil, Sitophilus zeamais Motschulsky (Coleoptera: Curculionidae). African J. Biotechnol. 7, 2957-2962.

Belmain, S.R., Amoah, B.A., Nyirenda, S.P., Kamanula, J.F., Stevenson, P.C., 2012 Highly variable insect control efficacy of Tephrosia vogelii chemotypes. J. Agr. Food Chem. 60, 10055-10063. doi: 10.1021/jf3032217

Castaño-Quintana, K., Montoya-Lerma, J., Giraldo-Echeverri, C. 2013. Toxicity of foliage extracts of Tithonia diversifolia (Asteraceae) on Atta cephalotes (Hymenoptera: Myrmicinae) workers. Ind. Crops Prod. 44, 391-395. doi: 10.1016/j.indcrop.2012.11.039

CCD, 2017 CCD 20.2 Copyright (C) 2017 Taylor \& Francis Group. http://ccd.chemnetbase.com/. Accessed 1 Dec 2016. 
De Toledo, J.S., Ambrósio, S.R., Borges, C.H.G., Manfrim, V., Cerri, D.G., Cruz, A.K., Da Costa, F.B., 2014. In Vitro Leishmanicidal Activities of Sesquiterpene Lactones from Tithonia diversifolia against Leishmania braziliensis Promastigotes and Amastigotes. Molecules 19, 6070-6079. doi: 10.3390/molecules19056070

Dutta P., Bhattacharyya, P.R., Rabha, L.C., Bordoloi, D.N., Barua, N.C., Chowdhury, P.K., Sharma, R.P., Barua, J.N., 1986. Feeding deterrents for Philosamia ricini (Samia cynthia subsp. Ricini) from Tithonia diversifolia. Phytoparasitica 14, 77-80. doi: 10.1007/BF02980481

Ehlers J.D., Hall, A.E., 1997. Cowpea (Vigna unguiculata L. Walp.). F. Crop Res. 53, 187204. doi: 10.1016/S0378-4290(97)00031-2

Erasto, P., Grierson, D.S., Afolayan, A.J.. 2006. Bioactive sesquiterpene lactones from the leaves of Vernonia amygdalina. J. Ethnopharmacol. 106,117-120. doi: 10.1016/j.jep.2005.12.016

Ganjian, I., Kubo, I., Fludzinski, P., 1983. Insect antifeedant elemanolide lactones from Vernonia amygdalina. Phytochemistry 22, 2525-2526. doi: 10.1016/0031-9422(83)80154-X

García, A., Delgado, G., Nathan, P.J., 2006. Constituents from Tithonia diversifolia. Stereochemical Revision of $2 \alpha \alpha$-Hydroxytirotundin. J. Mex. Chem. Soc. 50, 180-183.

Glaser, R., García, A., Chávez, M.I., Delgado, G., 2005. The Solid-State and Solution-State Reassigned Structures of Tagitinin A, a 3,10-Epoxy- Germacrolide from Tithonia diversifolia, and the Interconversion of 3,10-Epoxy-Germacrolide Conformational Families via a Ring-Atom Flip Mechanism. J. Braz. Chem. Soc. 16, 440-448.

Gurr, G.M., Wratten, S.D., Landis, D.A., You, M., 2017. Habitat Management to Suppress Pest Populations: Progress and Prospects. Annu. Rev. Entomol. 62, 91-109. doi: 10.1146/annurev-ento-031616-035050

Hagemann, J.W., Pearl, M.B., Higgins, J.J., Delfel, N.E., Earle, F.R., 1972. Rotenone and deguelin in Tephrosia vogelii at several stages of maturity. J. Agr. Food Chem. 20, 906-908. doi: 10.1021/jf60182a029

Henderson, L., 2007. Invasive, naturalized and casual alien plants in southern Africa: a summary based on the Southern African Plant Invaders Atlas (SAPIA). Bothalia 37, 215248. doi: $10.4102 / a b c . v 37 i 2.322$

Hill, D.S., 1983. Agricultural Insect Pests of the Tropics and Their Control, Second. Cambridge University Press, Cambridge

Isman, M.B., Grieneisen, M.L. 2014. Botanical insecticide research: many publications, limited useful data. Trends Plant Sci. 19, 140-145. doi: 10.1016/j.tplants.2013.11.005

Kolawole, A.O., Okonji, R.E., Ajele, J.O. 2011. Tithonia diversifolia, Cyperus rotundus and Hyptis suaveloensis ethanol extracts combinatorially and competitively inhibit affinity purified cowpea storage bruchid (Callosobrochus maculatus) glutathione S-transferase. Arthropod-Plant Inte. 5, 175-184. doi: 10.1007/s11829-011-9126-7 
Madkour, M.H., Zaitoun, A.A., Singer, F.A. 2013. Repellent and toxicity of crude plant extracts on saw-toothed grain beetle (Oryzaephilus surinamensis L.). J. Food Agric. Environ. $11,381-384$.

Matthews, G.A., Bateman, R., Miller, P., Thompson, S. 2014. Pesticide Application Methods, 4th edn. Wiley-Blackwell

Mkenda, P.A., Stevenson, P.C., Ndakidemi, P., Farman, D., Belmain, S.R., 2015a. Contact and fumigant toxicity of five pesticidal plants against Callosobruchus maculatus (Coleoptera: Chrysomelidae) in stored cowpea (Vigna unguiculata). Int. J. Trop. Insect Sci. 35,172-184. doi: $10.1017 / \mathrm{s} 174275841500017 \mathrm{x}$

Mkenda, P.A., Mwaauta, R., Stevenson, P.C., Ndakidemi, P., Mtei, K., Belmain, S.R., $2015 b$. Extracts from field margin weeds provide economically viable and environmentally benign pest control compared to synthetic pesticides. PLoS One 10, e0143530. doi:

10.1371/journal.pone.0143530

Mwine, J., Van Damme, P., Kamoga, G., Kudamba, M.N., Jumba, F., 2011. Ethnobotanical survey of pesticidal plants used in South Uganda: Case study of Masaka district. J. Med. Plants Res. 5,1155-1163.

Orsomando, G., Agostinelli, S., Bramucci, M., Cappellacci, L., Damiano, S., Lupidi, G., Maggi, F., Ngahang Kamte, S.L., Biapa Nya, P.C., Papa, F., 2016. Mexican sunflower (Tithonia diversifolia, Asteraceae) volatile oil as a selective inhibitor of Staphylococcus aureus nicotinate mononucleotide adenylyltransferase (NadD). Ind. Crops Prod. 85, 181-189. doi: 10.1016/j.indcrop.2016.03.003

Owolade, O.F., Alabi, B.S., Osikanlu, Y.O.K., Odeyemi, O.O., 2004. On-farm evaluation of some plant extracts as biofungicide and bioinsecticide on cowpea in Southwest Nigeria. Agric. Environ. 22, 237-240.

Passoni, F.D., Oliveira, R.B., Chagas-Paula, D.A., Gobbo-Neto, L., Da Costa, F.B., 2013. Repeated-dose toxicological studies of Tithonia diversifolia (Hemsl.) A. Gray and identification of the toxic compounds. J. Ethnopharmacol. 147, 389-394. doi: 10.1016/j.jep.2013.03.024

Sola, P., Mvumi, B.M., Ogendo, J.O., Mponda, O., Kamanula, J.F., Belmain, S.R., Stevenson, P.C., 2014. Botanical pesticide production, trade and regulatory mechanisms in sub-Saharan Africa: making a case for plant-based pesticidal products. Food Sec. 6, 369-384. doi: 10.1007/s12571-014-0343-7

Stevenson, P.C., Dayarathna, T.K., Belmain, S.R., Veitch, N.C., 2009. Bisdesmosidic saponins from Securidaca longepedunculata roots: evaluation of deterrency and toxicity to coleopteran storage pests. J. Agric. Food Chem. 57, 8860-8867. doi: 10.1021/jf901599j

Stevenson, P.C., Green, P.W.C., Veitch, N.C., Farrell, I.W., Kusolwa, P., Belmain, S.R., 2016. Nor-hopanes from Zanha africana root bark with toxicity to bruchid beetles. Phytochemistry 123, 25-32. doi: 10.1016/j.phytochem.2016.01.008

Stevenson, P.C., Kite, G.C., Lewis, G.P., Forest, F., Nyirenda, S.P., Belmain, S.R., Sileshi, G.W., Veitch, N.C., 2012. Distinct chemotypes of Tephrosia vogelii and implications for 
their use in pest control and soil enrichment. Phytochemistry 78,135-146. doi: 10.1016/j.phytochem.2012.02.025

Tuda, M., Rönn, J., Buranapanichpan, S., Wasano, N., Arnqvist, G., 2006. Evolutionary diversification of the bean beetle genus Callosobruchus (Coleoptera: Bruchidae): traits associated with stored-product pest status. Mol. Ecol. 15, 3541-3551. doi: 10.1111/j.1365294X.2006.03030.x

Van Alebeek, F.A.N., 1996. Natural suppression of bruchid pests in stored cowpea (Vigna unguiculata (L.) (Walp.) in West Africa. Int. J. Pest. Manag. 42, 55-60. doi: 10.1080/09670879609371970

Yang, J., Tang, L., Guan, Y.-L., Sun, W.-B., 2012. Genetic diversity of an alien invasive plant Mexican sunflower (Tithonia diversifolia) in China. Weed Sci. 60, 552-557. doi: 10.1614/WS-D-11-00175.1

Zhao, G.-J., Xi, Z.-X., Chen, W.-S., Li, X., Sun, L., Sun, L.-N., 2012. Chemical constituents from Tithonia diversifolia and their chemotaxonomic significance. Biochem. Syst. Ecol. 44, 250-254. doi: 10.1016/j.bse.2012.06.019 
Figure 1: Tagitinins identified in fractions from T. diversifolia ${ }^{\#}$

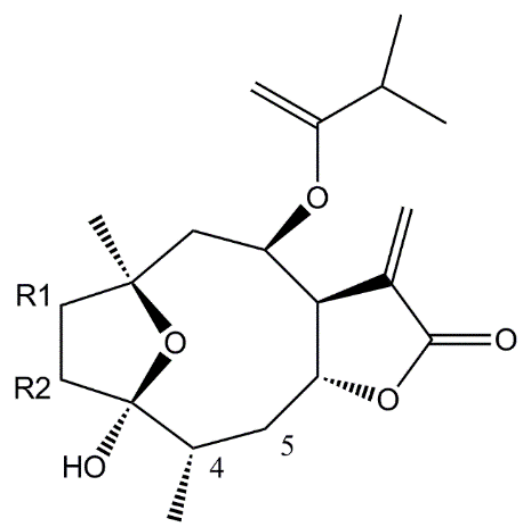

$\begin{array}{llr}\text { R1=OH; R2=H } & \text { Tagitinin A } & \text { T5 } \\ \text { R1=H; R2=OH; desaturation 4 to 5 } & \text { Tagitinin B } & \text { T11 } \\ \text { R1=H; R2=H } & \text { Tagitinin D } & \text { T14 }\end{array}$

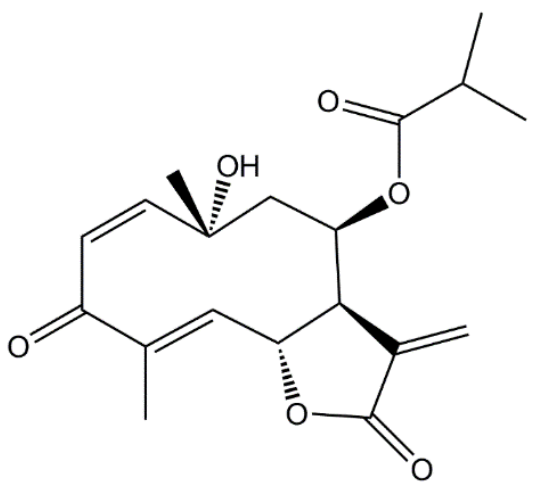

Tagitinin C $\quad$ T12

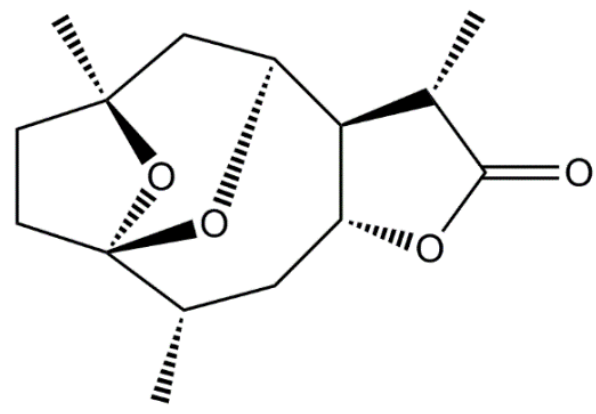

Tagitinin $\mathrm{H} \quad \mathbf{T 4}$

\# letters in bold after each compound name correspond to the compound number in Table 2. 
Figure 2: Flavones and related compounds tentatively identified from $T$. diversifolia and $V$. amygdalina ${ }^{\#}$.<smiles>[R6]c1cc(O)c2c(=O)cc(-c3ccc(OC)c(OC)c3)oc2c1</smiles>

$$
\begin{array}{lll}
\mathrm{R}=\mathrm{H} & \text { homohesperitin } & \text { T3 } \\
\mathrm{R}=\text { glc-rha } & \text { homohesperitin-7-rutinoside } & \text { V32 }
\end{array}
$$

\begin{tabular}{|c|c|}
\hline $\mathrm{R} 1=\mathrm{O}-\mathrm{xyl} ; \mathrm{R} 2=\mathrm{H}, \mathrm{R} 3=\mathrm{H} ; \mathrm{R} 4=\mathrm{H}$ & luteolin-3'-xyloside \\
\hline $\mathrm{R} 1=\mathrm{OCH}_{3} ; \mathrm{R} 2=\mathrm{H} ; \mathrm{R} 3=\mathrm{OH} ; \mathrm{R} 4=\mathrm{H}$ & luteolin-3'-methyl ether \\
\hline $\mathrm{R} 1=\mathrm{OH} ; \mathrm{R} 2=\mathrm{glc} ; \mathrm{R} 3=\mathrm{H} ; \mathrm{R} 4=\mathrm{H}$ & cymaroside \\
\hline $\mathrm{R} 1=\mathrm{H} ; \mathrm{R} 2=\mathrm{H} ; \mathrm{R} 3=\mathrm{OH} ; \mathrm{R} 4=\mathrm{H}$ & luteolin \\
\hline $\mathrm{R} 1=\mathrm{H} ; \mathrm{R} 2=\mathrm{OH} ; \mathrm{R} 3=\mathrm{H} ; \mathrm{R} 4=\mathrm{OCH}_{3}$ & hispidulin \\
\hline
\end{tabular}<smiles>[R2]c1cc2oc(-c3cc([R])c(O)c([R3])c3)cc(=O)c2c(O)c1[R4]</smiles>

\# letters in bold after each compound name correspond to the compound number in Tables 2 and 3 
Figure 3: Sesquiterpene lactones tentatively identified in fractions from V. amygdalina ${ }^{\#}$<smiles>[2H]C=C(CO)C(=O)O[C@H]1C[C@@]2(C=C)COC(=O)C(=C)[C@@]2([CH])[C@H]2OC(=O)C(C)[C@H]12</smiles>

11, 13-dihydrovernodalin V1<smiles>[2H]C=C(CO)C(=O)O[C@H]1C[C@@]2(C=C)COC(=O)C(=C[2H])[C@@]2(C)[C@H](O)[C@@H]1C(=C)C(=O)O</smiles>

Vernodalinol V4

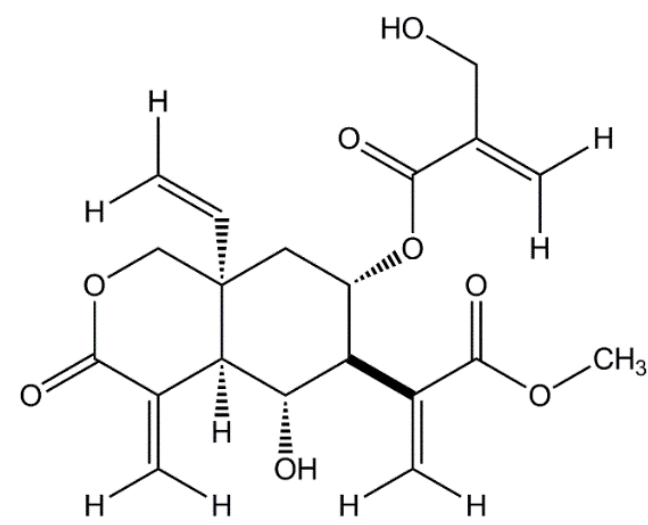

Vernodalol V10

\# letters in bold after each compound name correspond to the compound number in Table 3. 
Figure 4: Dimethyl-, dihexosyl caffeic acid tentatively identified in fractions from $V$. amygdalina ${ }^{\#}$<smiles>COc1ccc(/C=C/C(=O)OC2OC(C)C(O)C(O)C2OC2OC(CO)C(O)C(O)C2O)cc1OC</smiles>

V5

\# letters in bold correspond to the compound number in Table 3. 
Figure 5: Vernoniosides and a vernocuminoside tentatively identified in fractions from $V$. amygdalina

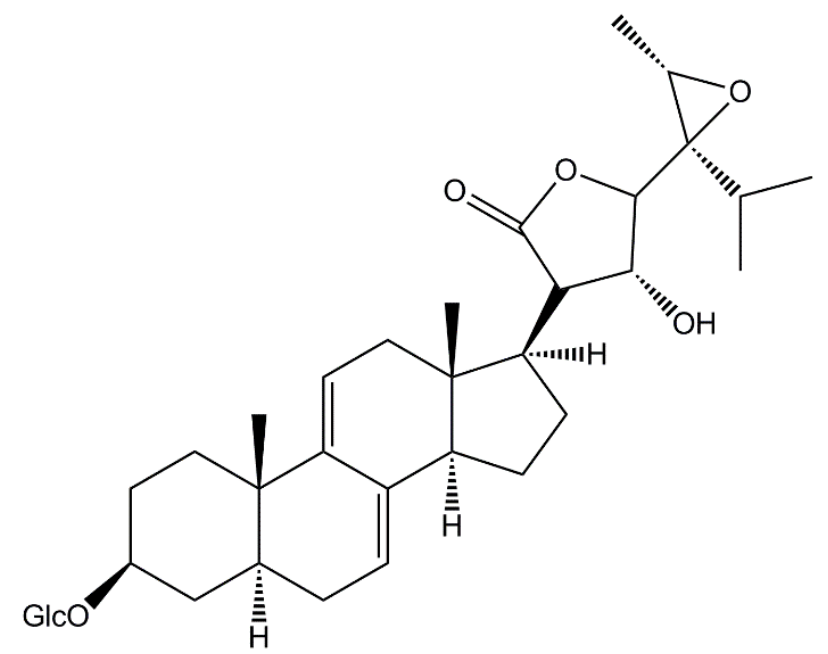

Vernonioside $\mathrm{B} 1\left(\mathrm{C}_{35} \mathrm{H}_{52} \mathrm{O}_{10}\right)$ V19, 22, 23, 27, 31

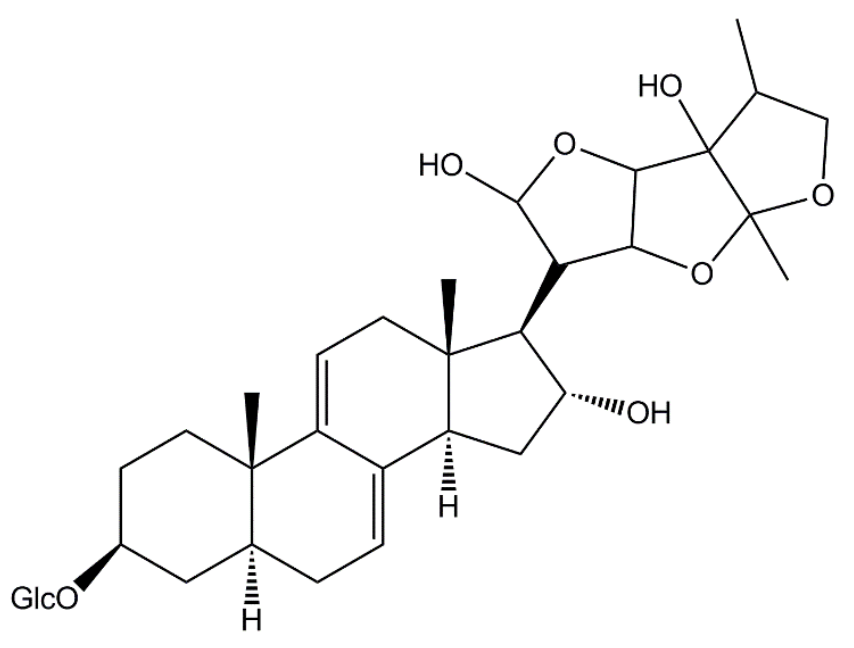

Vernonioside $\mathrm{D}\left(\mathrm{C}_{35} \mathrm{H}_{52} \mathrm{O}_{12}\right)$ V11

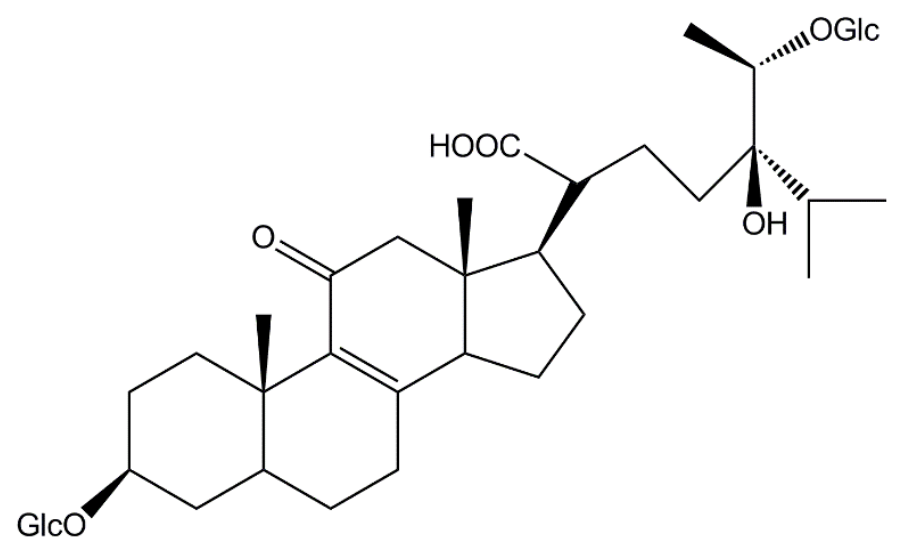

Vernocuminoside $\mathrm{G}:\left(\mathrm{C}_{41} \mathrm{H}_{66} \mathrm{O}_{16}\right)$ V6, 8

\footnotetext{
\# letters in bold correspond to the compound numbers in Table 3.
} 
Table 1 Mortality and total eggs laid by C. maculatus when exposed to different concentrations of fractions prepared from extracts of Tithonia diversifolia and Vernonia amygdalina for 6 days \#.

\begin{tabular}{|c|c|c|}
\hline $\begin{array}{l}\text { Treatment } \\
\text { [ppm for extracts] }\end{array}$ & LSD mean Mortality & LSD mean eggs laid, per female \\
\hline \multicolumn{3}{|l|}{ EXTRACTS } \\
\hline Tith $10 \%[11,480]$ & $92.611 \mathrm{abcd}$ & $23.678 \mathrm{abc}$ \\
\hline Tith $1 \%$ [114.8] & 92.424 abcd & 20.270 abcde \\
\hline Tith $0.1 \%$ [11.5] & $77.027 \mathrm{def}$ & 17.507 abcdef \\
\hline Vern $10 \%[7,740]$ & 90.238 abcd & 19.378 abcde \\
\hline Vern $1 \%[774]$ & $89.841 \mathrm{abcd}$ & 15.735 abcdefg \\
\hline \multicolumn{3}{|l|}{ Vern $0.1 \%[7.7]$} \\
\hline FRACTIONS & 82.567 abcde & 20.105 abcde \\
\hline Tith F1 (Tagitinin A) 488ppm & $60.462 \mathrm{f}$ & $23.467 \mathrm{abc}$ \\
\hline Tith F1 (Tagitinin A) 48.8ppm & $100.000 \mathrm{a}$ & 17.027 abcdef \\
\hline Tith F1 (Tagitinin A) 4.88ppm & $98.750 \mathrm{ab}$ & $13.088 \mathrm{bcdefg}$ \\
\hline Tith F2 95.2ppm & $98.571 \mathrm{ab}$ & $2.383 \mathrm{~g}$ \\
\hline Tith F2 9.52ppm & $95.123 \mathrm{abcd}$ & 12.520 bcdefg \\
\hline Tith F2 0.952ppm & $98.000 \mathrm{abc}$ & 17.113 abcdef \\
\hline Tith F3 80.5ppm & $90.059 \mathrm{abcd}$ & 11.677 cdefg \\
\hline Tith F3 8.05ppm & 85.844 abcd & $9.233 \mathrm{defg}$ \\
\hline Tith F3 0.81ppm & $100.000 \mathrm{a}$ & 14.960 abcdefg \\
\hline Tith F4 295.7ppm & $100.000 \mathrm{a}$ & 13.428 bcdefg \\
\hline Tith F4 29.57ppm & $87.071 \mathrm{abcd}$ & $20.977 \mathrm{abcd}$ \\
\hline Tith F4 2.96ppm & $96.333 \mathrm{abcd}$ & 16.597 abcdef \\
\hline Tith F5 260.1ppm & $95.500 \mathrm{abcd}$ & 13.292 bcdefg \\
\hline Tith F5 26ppm & $93.389 \mathrm{abcd}$ & 18.543 abcdef \\
\hline Tith F5 2.6ppm & $95.794 \mathrm{abcd}$ & $6.667 \mathrm{efg}$ \\
\hline Vern F1 265.1ppm & $91.813 \mathrm{abcd}$ & 20.183 abcde \\
\hline Vern F1 26.5ppm & $89.143 \mathrm{abcd}$ & 16.793 abcdef \\
\hline Vern F1 2.65ppm & $93.294 \mathrm{abcd}$ & 13.977 abcdefg \\
\hline Vern F2 173.3ppm & 87.908 abcd & 14.985 abcdefg \\
\hline Vern F2 17.3ppm & 90.806 abcd & 20.205 abcde \\
\hline Vern F2 1.73ppm & $78.063 \mathrm{cdef}$ & 19.188 abcdef \\
\hline Vern F3 179ppm & 84.149 abcde & $23.045 \mathrm{abc}$ \\
\hline Vern F3 17.9ppm & 81.452 abcde & $22.340 \mathrm{abcd}$ \\
\hline Vern F3 1.79ppm & 79.852 abcdef & 18.155 abcdef \\
\hline Vern F4 501.5ppm & 79.159 bcdef & $20.692 \mathrm{abcd}$ \\
\hline Vern F4 50.1ppm & 83.357 abcde & $24.185 \mathrm{abc}$ \\
\hline Vern F4 5.0ppm & $90.060 \mathrm{abcd}$ & 20.187 abcde \\
\hline Vern F5 355.79ppm & 78.927 bcdef & $27.630 \mathrm{a}$ \\
\hline Vern F5 35.58ppm & $86.440 \mathrm{abcd}$ & $20.823 \mathrm{abcd}$ \\
\hline Vern F5 3.56ppm & 65.204 ef & $26.203 \mathrm{ab}$ \\
\hline Rotenone 1000ppm & $97.571 \mathrm{abc}$ & 15.020 abcdefg \\
\hline Rotenone 100ppm & $97.778 \mathrm{abc}$ & $5.588 \mathrm{fg}$ \\
\hline Control & $20.453 \mathrm{~g}$ & $20.562 \mathrm{abcd}$ \\
\hline SEM & 2.485 & 3.647 \\
\hline$p>\mathrm{F}$ & 0 & 0 \\
\hline Significant & yes & yes \\
\hline
\end{tabular}


\# Values with the same letter are not different Tukey`s post hoc HSD-test (95\% C.I.). Tith=Tithonia;

Vern=Vernonia; F1, F2 etc=fraction number, followed by the concentration of the sample applied to the vials, as a w/v percentage equivalent for extracts, or in parts per million for the compound and fractions. 
Table 2: Summary of analyses of fractions from Tithonia diversifolia

\begin{tabular}{|c|c|c|c|c|c|}
\hline Compound & $\begin{array}{l}\text { Retention } \\
\text { time }\end{array}$ & $\begin{array}{l}m / z, \text { FTMS (relative } \\
\text { intensity) }\end{array}$ & $\begin{array}{l}\text { Molecular formula of compound and } \\
\text { identification }\end{array}$ & Fraction(s) & Additional information \\
\hline T1 & 8.31 & $187.09773^{-}$ & {$\left[\mathrm{C}_{9} \mathrm{H}_{15} \mathrm{O}_{4}\right]^{-}$, not identified } & 5 & \\
\hline $\mathrm{T} 2$ & 9.64 & $241.10835[\mathrm{M}-\mathrm{H}]^{-}$ & {$\left[\mathrm{C}_{12} \mathrm{H}_{17} \mathrm{O}_{5}\right]^{-}$, not identified } & 5 & \\
\hline T3 & 9.82 & $315.05048[\mathrm{M}-\mathrm{H}]^{-}$ & $\mathrm{C}_{17} \mathrm{H}_{16} \mathrm{O}_{6}$, homohesperitin & 2 & $U V=235,250 \mathrm{sh}, 270 \mathrm{sh}, 346 \mathrm{~nm}$ \\
\hline T4 & 9.99 & $267.12198[\mathrm{M}+\mathrm{H}]^{+}$ & $\mathrm{C}_{15} \mathrm{H}_{22} \mathrm{O}_{4}$, tagitinin $\mathrm{H}$ & 5 & \\
\hline T5 & 10.08 & $413.18170[\mathrm{M}+\mathrm{FA}-\mathrm{H}]^{-}$ & $\mathrm{C}_{19} \mathrm{H}_{28} \mathrm{O}_{7}$, tagitinin $\mathrm{A}$ & 1,2 & \\
\hline T6 & 10.52 & $413.18112[\mathrm{M}+\mathrm{FA}-\mathrm{H}]^{-}$ & $\begin{array}{l}\mathrm{C}_{19} \mathrm{H}_{28} \mathrm{O}_{7}, 2 \mathrm{a} \text {-hydroxyrotundin or } \\
\text { 1,4-Epoxy-1,3,8-trihydroxy-11(13)-germacren- } \\
\text { 12,6-olide; }(1 \alpha, 3 \beta, 6 \beta, 8 \alpha, 10 \alpha) \text {-form, 8-O-(2- } \\
\text { Methylpropanoyl). }\end{array}$ & 2 & $\begin{array}{l}\text { 1,4-epoxy- isolated from } \\
\text { Picrasma javanica } \\
\text { (Simaroubaceae) }\end{array}$ \\
\hline $\mathrm{T7}$ & 10.59 & $411.16559[\mathrm{M}+\mathrm{FA}-\mathrm{H}]^{-}$ & 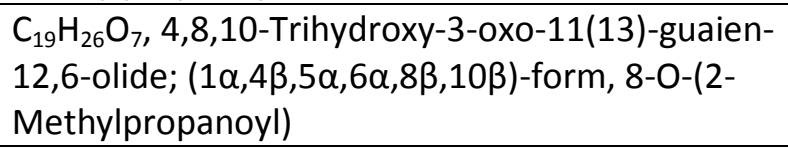 & 4 & \\
\hline T8 & 11.16 & $299.05508[\mathrm{M}-\mathrm{H}]^{-}$ & Hispidulin & 3 & $U V=236,273 \mathrm{sh}, 335 \mathrm{~nm}$ \\
\hline T9 & 11.41 & $413.18167[\mathrm{M}+\mathrm{FA}-\mathrm{H}]^{-}$ & $\begin{array}{l}\mathrm{C}_{19} \mathrm{H}_{28} \mathrm{O}_{7}, 2 \mathrm{a}-\text { hydroxyrotundin or 1,4-Epoxy-1,3,8- } \\
\text { trihydroxy-11(13)-germacren-12,6-olide; } \\
(1 \alpha, 3 \beta, 6 \beta, 8 \alpha, 10 \alpha) \text {-form, } 8-O-(2- \\
\text { Methylpropanoyl). }\end{array}$ & 2 & $\begin{array}{l}\text { 1,4-epoxy- isolated from } \\
\text { Picrasma javanica } \\
\text { (Simaroubaceae) }\end{array}$ \\
\hline T10 & 11.53 & $409.15063[\mathrm{M}+\mathrm{FA}-\mathrm{H}]^{-}$ & $\begin{array}{l}\mathrm{C}_{19} \mathrm{H}_{24} \mathrm{O}_{7}, 8 \text { 8-Hydroxy-4-oxo-3,4-seco-11(13)- } \\
\text { guaiene-3,10:12,6-diolide; }(1 \alpha, 5 \alpha, 6 \alpha, 8 \beta, 10 \alpha) \text { - } \\
\text { form, 8-O-(2-Methylpropanoyl) }\end{array}$ & 5 & \\
\hline T11 & 11.84 & $411.16574[\mathrm{M}+\mathrm{FA}-\mathrm{H}]^{-}$ & $\mathrm{C}_{19} \mathrm{H}_{26} \mathrm{O}_{7}$, tagitinin $\mathrm{B}$ & 2 & \\
\hline T12 & $\begin{array}{l}11.87 \text { and } \\
11.91\end{array}$ & $393.15503[\mathrm{M}+\mathrm{FA}-\mathrm{H}]^{-}$ & $\mathrm{C}_{19} \mathrm{H}_{24} \mathrm{O}_{6}$, tagitinin $\mathrm{C}$ & $3,4,5$ & $U V=236,250 \mathrm{sh} \mathrm{nm}$ \\
\hline T13 & 12.17 & $425.18112[\mathrm{M}+\mathrm{FA}-\mathrm{H}]^{-}$ & $\begin{array}{l}\mathrm{C}_{20} \mathrm{H}_{28} \mathrm{O}_{7}, 2-O \text {-methyl tagitinin } \mathrm{B} \text {, tirotundifolin } \mathrm{E} \text {, } \\
\text { tithonin or 3,10-Epoxy-1,3,8-trihydroxy-4,11(13)- } \\
\text { germacradien-12,6-olide; }(1 \beta, 3 \alpha, 4 Z, 6 \alpha, 8 \beta) \text {-form, } \\
\text { 3-Me ether, 8-O-(2-methylpropanoyl) }\end{array}$ & 2 & \\
\hline T14 & 12.59 & $351.14456[\mathrm{M}-\mathrm{H}]^{-}$ & $\mathrm{C}_{19} \mathrm{H}_{28} \mathrm{O}_{6}$, tagitinin $\mathrm{D}$ & 3 & \\
\hline T15 & 12.84 and & $379.17642[\mathrm{M}-\mathrm{H}]^{-}$ & $\mathrm{C}_{20} \mathrm{H}_{28} \mathrm{O}_{7}, 2-\mathrm{O}$-methyl tagitinin $\mathrm{B}$, tirotundifolin $\mathrm{E}$, & 2,4 & \\
\hline
\end{tabular}




\begin{tabular}{|c|c|c|c|c|c|}
\hline Compound & $\begin{array}{l}\text { Retention } \\
\text { time }\end{array}$ & $\begin{array}{l}m / z, \text { FTMS (relative } \\
\text { intensity) }\end{array}$ & $\begin{array}{l}\text { Molecular formula of compound and } \\
\text { identification }\end{array}$ & Fraction(s) & Additional information \\
\hline & 12.86 & & $\begin{array}{l}\text { tithonin or 3,10-Epoxy-1,3,8-trihydroxy-4,11(13)- } \\
\text { germacradien-12,6-olide; }(1 \beta, 3 \alpha, 4 Z, 6 \alpha, 8 \beta) \text {-form, } \\
\text { 3-Me ether, 8-O-(2-methylpropanoyl) }\end{array}$ & & \\
\hline T16 & $\begin{array}{l}14.17 \text { to } \\
14.20\end{array}$ & $381.175328[\mathrm{M}-\mathrm{H}]^{-}$ & $\begin{array}{l}\mathrm{C}_{20} \mathrm{H}_{28} \mathrm{O}_{7}, 2-\mathrm{O} \text {-methyl tagitinin } \mathrm{B} \text {, tirotundifolin } \mathrm{E} \text {, } \\
\text { tithonin or 3,10-Epoxy-1,3,8-trihydroxy-4,11(13)- } \\
\text { germacradien-12,6-olide; }(1 \beta, 3 \alpha, 4 Z, 6 \alpha, 8 \beta) \text {-form, } \\
\text { 3-Me ether, 8-O-(2-methylpropanoyl) }\end{array}$ & $2,3,4$ & \\
\hline
\end{tabular}


Table 3: Summary of analyses of fractions from Vernonia amygdalina.

\begin{tabular}{|c|c|c|c|c|c|}
\hline Compound & $\begin{array}{l}\text { Retention } \\
\text { time }\end{array}$ & $\begin{array}{l}m / z, \text { FTMS (relative } \\
\text { intensity) }\end{array}$ & Molecular formula of compound & Fraction & $\begin{array}{l}\text { Additional information, UV } \\
\text { absorption in } \mathrm{nm}\end{array}$ \\
\hline V1 & 5.34 & $363.14377[\mathrm{M}+\mathrm{H}]^{+}$ & $\mathrm{C}_{19} \mathrm{H}_{22} \mathrm{O}_{7}, 11,13$-dihydrovernodalin & 1 & \\
\hline V2 & 6.78 & $449.10696[\mathrm{M}+\mathrm{H}]^{+}$ & $\mathrm{C}_{21} \mathrm{H}_{20} \mathrm{O}_{11}$, cynaroside (luteolin-7-glucoside) & 1,3 & $U V=235,253,266 \mathrm{sh}, 348 \mathrm{~nm}$ \\
\hline V3 & 6.91 & $461.07196[\mathrm{M}-\mathrm{H}]^{-}$ & $\mathrm{C}_{21} \mathrm{H}_{18} \mathrm{O}_{12}$, luteolin (3', 5 or 7 -hexuronide) & 1 & $U V=243,347 \mathrm{~nm}$ \\
\hline V4 & 7.59 & $377.12354[\mathrm{M}-\mathrm{H}]^{-}$ & $\mathrm{C}_{19} \mathrm{H}_{22} \mathrm{O}_{8}$, vernodalinol & 1 & UV=290sh, 326nm \\
\hline V5 & 7.68 & $515.11890[\mathrm{M}-\mathrm{H}]^{-}$ & $\mathrm{C}_{23} \mathrm{H}_{32} \mathrm{O}_{13}$, dimethyl, dihexosyl ester of caffeic acid & 1 & UV=290sh, $328 \mathrm{~nm}$ \\
\hline V6 & 8.17 & $859.43347[\mathrm{M}+\mathrm{FA}-\mathrm{H}]^{-}$ & $\mathrm{C}_{41} \mathrm{H}_{66} \mathrm{O}_{16}$, a vernocuminoside & 5 & \\
\hline V7 & 8.25 & $425.14484[\mathrm{M}+\mathrm{FA}-\mathrm{H}]^{-}$ & $\begin{array}{l}\mathrm{C}_{19} \mathrm{H}_{24} \mathrm{O}_{8} \text {, seven possible configurations known } \\
\text { from Vernonia spp. }\end{array}$ & 1 & \\
\hline V8 & 8.55 & $859.43384[\mathrm{M}+\mathrm{FA}-\mathrm{H}]^{-}$ & $\mathrm{C}_{41} \mathrm{H}_{66} \mathrm{O}_{16}$, a vernocuminoside & 5 & \\
\hline V9 & 8.66 & 429.17676 & {$\left[\mathrm{C}_{20} \mathrm{H}_{29} \mathrm{O}_{10}\right]^{\prime}$, not identified } & 2 & \\
\hline V10 & 8.7 & $437.14417[\mathrm{M}+\mathrm{FA}-\mathrm{H}]^{-}$ & $\mathrm{C}_{20} \mathrm{H}_{24} \mathrm{O}_{8}$, vernodalol & 1 & \\
\hline V11 & $9.10,9.11$ & $709.34448[\mathrm{M}+\mathrm{FA}-\mathrm{H}]^{-}$ & $\mathrm{C}_{35} \mathrm{H}_{52} \mathrm{O}_{12}$, vernonioside $\mathrm{D}$ & 4,5 & \\
\hline V12 & 9.40 & $843.60394[\mathrm{M}+\mathrm{FA}-\mathrm{H}]^{-}$ & $\mathrm{C}_{41} \mathrm{H}_{66} \mathrm{O}_{15}$, a vernocuminoside & 4,5 & \\
\hline V13 & 9.48 & $665.27881[\mathrm{M}+\mathrm{H}]^{+}$ & $\mathrm{C}_{35} \mathrm{H}_{52} \mathrm{O}_{12}$, a vernonioside & 4 & \\
\hline V14 & $9.66,9.69$ & $843.47894[\mathrm{M}+\mathrm{FA}-\mathrm{H}]^{-}$ & $\mathrm{C}_{41} \mathrm{H}_{66} \mathrm{O}_{15}$, a vernocuminoside & 4,5 & \\
\hline V15 & 9.75 & $285.03992[\mathrm{M}-\mathrm{H}]^{-}$ & $\mathrm{C}_{15} \mathrm{H}_{10} \mathrm{O}_{6}$, luteolin & 2 & $U V=236,253 \mathrm{sh}, 266 \mathrm{sh}, 348 \mathrm{~nm}$ \\
\hline V16 & 9.97 & $693.35400[\mathrm{M}+\mathrm{FA}-\mathrm{H}]^{-}$ & $\begin{array}{l}\mathrm{C}_{35} \mathrm{H}_{52} \mathrm{O}_{11} \text {, six possible configurations known from } \\
\text { Vernonia, mainly vernoniosides but including a } \\
\text { vernoamyoside. }\end{array}$ & 4 & \\
\hline V17 & 9.99 & $299.04455[\mathrm{M}-\mathrm{H}]^{-}$ & $\mathrm{C}_{16} \mathrm{H}_{12} \mathrm{O}_{6}$, luteolin methyl ether & 2 & $U V=235,283,335 \mathrm{~nm}$ \\
\hline V18 & 10.75 & 735.36096 & {$\left[\mathrm{C}_{38} \mathrm{H}_{55} \mathrm{O}_{14}\right]^{\prime}$, not identified } & 3 & $U V=236,243 \mathrm{~nm}$ \\
\hline V19 & 10.93 & $633.25232[\mathrm{M}+\mathrm{H}]^{+}$ & $\mathrm{C}_{35} \mathrm{H}_{52} \mathrm{O}_{10}$, a vernonioside & 4 & \\
\hline V20 & 10.98 & $651.37311[\mathrm{M}+\mathrm{H}]^{+}$ & $\mathrm{C}_{35} \mathrm{H}_{54} \mathrm{O}_{11}$, a vernonioside & 3 & $\begin{array}{l}\text { UV }=236,250,330 \mathrm{~nm} \\
\text { Possible saturation of a single } \\
\text { bond to increase MW by two } \\
\text { hydrogens, from known } \\
\text { compounds, such as vernonioside } \\
\mathrm{A}_{4}\end{array}$ \\
\hline V21 & 11.1, & $693.34894[\mathrm{M}+\mathrm{FA}-\mathrm{H}]^{-}$ & $\mathrm{C}_{35} \mathrm{H}_{52} \mathrm{O}_{11}$, a vernonioside & 2,3 & $U V=240,250 \mathrm{~nm}$ \\
\hline
\end{tabular}




\begin{tabular}{|c|c|c|c|c|c|}
\hline Compound & $\begin{array}{l}\text { Retention } \\
\text { time }\end{array}$ & $\begin{array}{l}m / z, \text { FTMS (relative } \\
\text { intensity) }\end{array}$ & Molecular formula of compound & Fraction & $\begin{array}{l}\text { Additional information, UV } \\
\text { absorption in } \mathrm{nm}\end{array}$ \\
\hline & 11.12 & & & & \\
\hline V22 & $\begin{array}{l}11.36 \\
11.38\end{array}$ & $677.35510[\mathrm{M}+\mathrm{FA}-\mathrm{H}]^{-}$ & $\mathrm{C}_{35} \mathrm{H}_{52} \mathrm{O}_{10}$, a vernonioside & $3,4,5$ & $U V=240,243 \mathrm{~nm}$ \\
\hline V23 & 11.61 & $677.35425[\mathrm{M}+\mathrm{FA}-\mathrm{H}]^{-}$ & $\mathrm{C}_{35} \mathrm{H}_{52} \mathrm{O}_{10}$, a vernonioside & 3 & $U V=243,246 \mathrm{~nm}$ \\
\hline V24 & 11.73 & $825.42908[\mathrm{M}+\mathrm{FA}-\mathrm{H}]^{-}$ & $\mathrm{C}_{41} \mathrm{H}_{64} \mathrm{O}_{14}$, a vernonioside & 5 & \\
\hline V25 & 11.95 & $675.33826[\mathrm{M}+\mathrm{FA}-\mathrm{H}]^{-}$ & $\mathrm{C}_{35} \mathrm{H}_{50} \mathrm{O}_{10}$, a vernonioside & 3 & UV=240, $246 \mathrm{~nm}$ \\
\hline V26 & 12.07 & $\begin{array}{l}911.42392\left[\mathrm{C}_{45} \mathrm{H}_{67} \mathrm{O}_{19}\right]^{-}(100) \\
681.38623[\mathrm{M}-\mathrm{H}]^{-}(10)\end{array}$ & $\mathrm{C}_{36} \mathrm{H}_{58} \mathrm{O}_{12}$, a vernonioside & 5 & $\begin{array}{l}\text { Possible saturation of a single } \\
\text { bond to increase MW by two } \\
\text { hydrogens, from known } \\
\text { compounds, such as vernonioside } \\
\mathrm{B}_{2}\end{array}$ \\
\hline V27 & 12.28 & $677.47559[\mathrm{M}+\mathrm{FA}-\mathrm{H}]^{-}$ & $\mathrm{C}_{35} \mathrm{H}_{52} \mathrm{O}_{10}$, a vernonioside & 4 & UV=238, $243 \mathrm{~nm}$ \\
\hline V28 & 12.37 & $411.16620[\mathrm{M}-\mathrm{H}]^{-}$ & $\mathrm{C}_{19} \mathrm{H}_{24} \mathrm{O}_{10}$, four possible 12 , 6-germacronolides & 2 & \\
\hline V29 & 12.50 & $725.37634[\mathrm{M}+\mathrm{FA}-\mathrm{H}]^{-}$ & $\mathrm{C}_{36} \mathrm{H}_{56} \mathrm{O}_{12}$, a vernonioside & 5 & \\
\hline V30 & 12.84 & $675.49408[\mathrm{M}+\mathrm{H}]^{+}$ & $\mathrm{C}_{37} \mathrm{H}_{54} \mathrm{O}_{11}$, a vernonioside & 4 & \\
\hline V31 & 13.32 & $677.47314[\mathrm{M}+\mathrm{FA}-\mathrm{H}]^{-}$ & $\mathrm{C}_{35} \mathrm{H}_{52} \mathrm{O}_{10}$, a vernonioside & 4,5 & $U V=238,243 \mathrm{~nm}$ \\
\hline V32 & 14.41 & $661.35931[\mathrm{M}+\mathrm{FA}-\mathrm{H}]^{-}$ & $\mathrm{C}_{29} \mathrm{H}_{36} \mathrm{O}_{15}$, homohesperitin 7-rutinoside & 5 & \\
\hline
\end{tabular}



Supplementary Interactive Plot Data (CSV)
Click here to download Supplementary Inte

Click here to download Supplementary Interactive Plot Data (CSV): Tithonia Manuscript Submitted INDCROPROD Supplementar (a)  西 西 (1) (1) . . . . . 